OPEN ACCESS

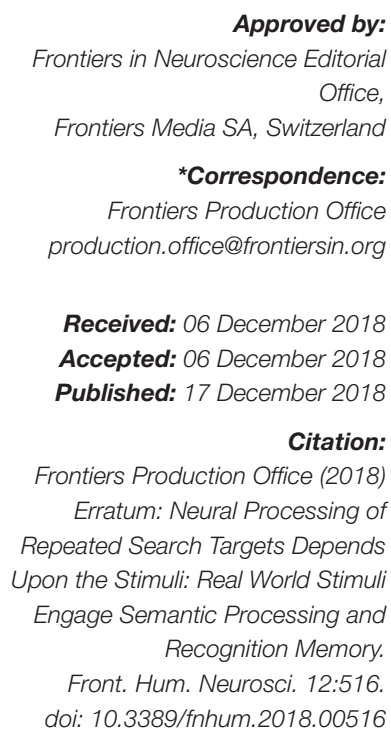

Approved by:

Frontiers in Neuroscience Editorial Office,

Frontiers Media SA, Switzerland

*Correspondence:

Frontiers Production Office production.office@frontiersin.org

Received: 06 December 2018 Accepted: 06 December 2018 Published: 17 December 2018

Citation:

Frontiers Production Office (2018)

Erratum: Neural Processing of Repeated Search Targets Depends Upon the Stimuli: Real World Stimuli

Engage Semantic Processing and Recognition Memory. Front. Hum. Neurosci. 12:516. doi: 10.3389/fnhum.2018.00516

\section{Erratum: Neural Processing of Repeated Search Targets Depends Upon the Stimuli: Real World Stimuli Engage Semantic Processing and Recognition Memory}

\author{
Frontiers Production Office* \\ Frontiers Media SA, Lausanne, Switzerland
}

Keywords: visual working memory, visual search, ERPs, CDA, N2pc, anterior N2, N400, LPC

\section{An Erratum on}

Neural Processing of Repeated Search Targets Depends Upon the Stimuli: Real World Stimuli Engage Semantic Processing and Recognition Memory

by Drew, T., Williams, L. H., Jones, C. M., and Luria, R. (2018). Front. Hum. Neurosci. 12:460. doi: 10.3389/fnhum.2018.00460

Due to a production error, affiliation 2 and 3 were inverted and therefore attributed to the wrong authors.

The correct affiliation for Christopher Michael Jones is: Department of Psychology, The Ohio State University, Columbus, $\mathrm{OH}$, United States. The correct affiliation for Roy Luria is: Sagol School of Neuroscience and the School of Psychological Science, Tel Aviv University, Tel Aviv, Israel.

The publisher apologizes for this mistake. The original article has been updated.

Copyright (-) 2018 Frontiers Production Office. This is an open-access article distributed under the terms of the Creative Commons Attribution License (CC BY). The use, distribution or reproduction in other forums is permitted, provided the original author(s) and the copyright owner(s) are credited and that the original publication in this journal is cited, in accordance with accepted academic practice. No use, distribution or reproduction is permitted which does not comply with these terms. 